PressAcademia Procedia

\title{
5G AND BANKING
}

\section{DOI: 10.17261/Pressacademia.2021.1501 PAP- V.14-2021(27)-p.117-118}

\section{Suat Teker ${ }^{1}$, Dilek Teker ${ }^{2}$, Irmak Orman ${ }^{3}$}

${ }^{1}$ Isik University, Department of Business, Sile Campus, Istanbul, Turkey. suat.teker@isikun.edu.tr ,ORCID: 0000-0002-7981-3121

${ }^{2}$ ssik University, Department of Business, Sile Campus, Istanbul, Turkey. dilek.teker@isikun.edu.tr, ORCID: 0000-0002-3893-4015

${ }^{3}$ ssik University, Department of Business, Sile Campus, Istanbul, Turkey. irmak.orman@isikun.edu.tr , ORCID: 0000-0002-5150-8168

\section{To cite this document}

Teker, S., Teker, D., Orman, I., (2021). 5 G and banking. PressAcademia Procedia (PAP), 14, 117-118.

Permanent link to this document: http://doi.org/10.17261/Pressacademia.2021.1501

Copyright: Published by PressAcademia and limited licensed re-use rights only.

\section{ABSTRACT}

Purpose- Technological developments in mobile telecommunications have evolved immensely after the transition from analog technologies that were widely used in 1980 s to digital technologies connecting to globe with wireless cellular technologies. This study intends to review telecommunication technologies starting 1970s (1G technology) through 2020s (5G technology) and analyze the expected effects of 5G technology on the future of banking sector. In addition, it is envisioned how $5 \mathrm{G}$ technology will shape the future of the banking industry.

Methodology- The study is conducted by having a comparative review of digital technology developments in the last 50 yearsThis study examines the effects of developments in communication technologies on the banking sector and banking services. The research design of this study is the relationship between the advancements in telecommunication technologies and the future of banking sector. The following section cover the comparison of 1G-2G-3G-4G-5G Technologies.

Findings- $5 \mathrm{G}$ banking featuring video communication, data protection and digital wallets will create a permanent shift for banking customers and their habits. Globally, bank customers are adopting to digital apps as their primary touchpoint for their banks and this transformation will change the structure of bank branches as well as financial services industry. As a result of the analysis, it has been observed that an important innovation and structural transformation period has been entered in the banking sector with the use of $3 \mathrm{G}$ and $4 \mathrm{G}$ compared to the year before 2000, which we define as traditional banking era.

Conclusion- With the wide use of $5 \mathrm{G}$ technology after year 2022, the banking sector is expected to enter a new and disruptive restructuring and service innovation. $5 \mathrm{G}$ is expected to carry the banking industry to another level where automation and machine-to-machine communication act as a game changer.

Keywords: $5 G$, banking technologies, advancements in telecommunication, future of banking.

JEL Codes: F10, G10, G20

\section{REFERENCES}

Aithal, S., Karani, K., Prasad. (2015). Massive Growth of Banking Technology with the Aid of 5G Technologies. International Journal of Technology Management, 5, 617-626.

Akın, F. (2020, June 2). Dijital Dönüşümün Bankacılık Sektörü Üzerindeki Etkileri, Balkan and Near Eastern Journal of Social Sciences, http://Ibaness.Org/Bnejss/2020_06_02/03_Akin.Pdf

Anjan V. Thakor,(2020). Fintech and Banking: What Do We Know?, Journal of Financial Intermediation, 41, 822833.https://Doi.Org/10.1016/J.Jfi.2019.100833.

Baicu, C.G., Gârdan, I. P., Gârdan, D.A., Epuran, G., (2020), The Impact of COVID-19 on Consumer Behavior in Retail Banking: Evidence from Romania. Management \& Marketing 15, 534-556.

Bertenyi B. (2021). 5G Evolution: What's Next? In IEEE Wireless Communications, 28(1), 4-8, Doi: 10.1109/MWC.2021.9363048. 
Dahlman E., Parkvall S., Peisa J. and Tullberg H. (2019). 5G Evolution and Beyond. 2019 IEEE 20th International Workshop on Signal Processing Advances in Wireless Communications (SPAWC), 1-5, Doi: 10.1109/SPAWC.2019.8815418.

Geylani M., Çıbuk M., Çınar H. ve Ağgün F., (2016). Geçmişten Günümüze Hücresel Haberleşme Teknolojilerinin Gelişimi. Dokuz Eylül Üniversitesi Mühendislik Fakültesi Fen ve Mühendislik Dergisi, 18(54), 606-623.

Ghosh A., Maeder A., Baker M. and Chandramouli D. (2019). 5G Evolution: A View on 5G Cellular Technology Beyond 3GPP Release 15. IEEE Access, 7, 127639-127651, DOI: 10.1109/ACCESS.2019.2939938.

Ginovsky, J. (2021). How $5 G$ will Reshape the Future of Digital Banking \& Payments the Financial Brand. Https://Thefinancialbrand.Com/119383/How-5g-Will-Reshape-The-Future-Of-Digital-Banking-Payments/

OECD (2019). Going Digital: Shaping Policies, Improving Lives, OECD Publishing, Paris, Https://Doi.Org/10.1787/9789264312012-En. (18.09.2021)

OECD (2019). A Measurement Roadmap for the Future. In Measuring The Digital Transformation: A Roadmap For The Future, OECD Publishing, Paris, Www.Oecd.Org/Going-Digital/Measurement-Roadmap.Pdf

OECD (2020). Digital Disruption in Banking and its Impact on Competition Http://Www.Oecd.Org/Daf/Competition/Digital-Disruption-InFinancial-Markets. Htm (18.09.2021)

J Place, S Keeping, S Akayama, A Schlautmann, (2012). The Business Benefits of 4G LTE. Arthur D Little, UK, https://www.adlittle.com/en/insights/43/financial-services (16.09.2021) 